\title{
A TRß-selective agonist confers resistance to diet-induced obesity
}

\author{
Beatriz S Amorim ${ }^{1,3, *}$, Cintia B Ueta ${ }^{1,3, *}$, Beatriz C G Freitas ${ }^{2}$, Renata J Nassif ${ }^{1}$, Cecília Helena \\ de Azevedo Gouveia ${ }^{3}$, Marcelo A Christoffolete ${ }^{4}$, Anselmo S Moriscot ${ }^{4}$, Carmen Lucia Lancelloti ${ }^{8}$, \\ Flávia Llimona ${ }^{6}$, Hermes Vieira Barbeiro ${ }^{6}$, Heraldo Possolo de Souza ${ }^{6}$, Sergio Catanozi ${ }^{5}$, \\ Marisa Passarelli ${ }^{5}$, Marcelo S Aoki ${ }^{7}$, Antonio C Bianco ${ }^{2}$ and Miriam O Ribeiro ${ }^{1}$ \\ ${ }^{1}$ Biological Science Course, CCBS, Presbyterian University Mackenzie, Rua da Consolação, 930 Prédio 38, Curso de Biologia, São Paulo, SP 01302-907, Brazil \\ ${ }^{2}$ Division of Endocrinology, Diabetes and Metabolism, University of Miami Miller School of Medicine, Miami, Florida 33136, USA \\ ${ }^{3}$ Department of Anatomy, Institute of Biomedical Sciences, ${ }^{4}$ Department of Cell and Developmental Biology, Institute of Biomedical Sciences, ${ }^{5}$ Lipids \\ Laboratory (LIM 10) Faculty of Medical Sciences, ${ }^{6}$ Clinical Emergency, Faculty of Medical Sciences and ${ }^{7}$ School of Arts, Sciences and Humanities, \\ University of São Paulo, São Paulo, SP, Brazil \\ ${ }^{8}$ AFIP and Pathology, School of Medical Sciences, Santa Casa, São Paulo 04020-060, SP, Brazil \\ (Correspondence should be addressed to M O Ribeiro; Email: miriamribeiro@mackenzie.br) \\ *(B S Amorim and C B Ueta contributed equally to this work)
}

\begin{abstract}
Thyroid hormone receptor $\beta$ (TR $\beta$ also listed as THRB on the MGI Database)-selective agonists activate brown adipose tissue (BAT) thermogenesis, while only minimally affecting cardiac activity or lean body mass. Here, we tested the hypothesis that daily administration of the TR $\beta$ agonist GC24 prevents the metabolic alterations associated with a hypercaloric diet. Rats were placed on a high-fat diet and after a month exhibited increased body weight (BW) and adiposity, fasting hyperglycemia and glucose intolerance, increased plasma levels of triglycerides, cholesterol, nonesterified fatty acids and interleukin-6. While GC-24 administration to these animals did not affect food ingestion or modified the progression of BW gain, it did increase energy expenditure, eliminating the increase in adiposity without
\end{abstract}

causing cardiac hypertrophy. Fasting hyperglycemia remained unchanged, but treatment with GC-24 improved glucose tolerance by increasing insulin sensitivity, and also normalized plasma triglyceride levels. Plasma cholesterol levels were only partially normalized and liver cholesterol content remained high in the GC-24-treated animals. Gene expression in liver, skeletal muscle, and white adipose tissue was only minimally affected by treatment with GC-24, with the main target being BAT. In conclusion, during high-fat feeding treatment with the TR $\beta$-selective agonist, GC-24 only partially improves metabolic control probably as a result of accelerating the resting metabolic rate.

Journal of Endocrinology (2009) 203, 291-299

\section{Introduction}

Thyroid hormone is a highly metabolic molecule. When given to animals and humans, it rapidly increases energy expenditure (Klitgaard et al. 1952), while lowering serum cholesterol (Hansson et al. 1983) and triglycerides (Abrams et al. 1981) levels. However, side effects resulting from the pleomorphic actions of thyroid hormone, such as cardiac arrhythmia (Klein \& Ojamaa 2001), bone loss (Ross 1994, Murphy \& Williams 2004, Galliford et al. 2005), nervousness, and anxiety (Placidi et al. 1998), to name a few, prevent it from widespread clinical use. Ideally, one would want to harness the beneficial metabolic effects of thyroid hormone mediated at the liver, adipose tissue, and skeletal muscle, while sparing the myocardium, bone, brain, and other tissues.

Our current understanding of thyroid hormone action allows for the development of such strategies. Tri-iodothyronine $\left(T_{3}\right)$ effects are mediated by thyroid hormone receptors
(TRs), which are ligand-dependent transcription factors that regulate the expression of different sets of genes involved not only in metabolic control, but also in development and growth (Yen 2001). The fact that the TR encoding genes are differentially expressed in various tissues indicates that the $T_{3}$ effects can be TR isoform specific. Also, studies in patients with syndrome of resistance to $\mathrm{T}_{3}$, and studies in mice with targeted disruption of TR $\alpha, T R \beta$, (listed as THRA and THRB on the MGI Database) or both, have illustrated selective functions of TRs, and some actions that are preferentially triggered by a specific TR isoform (Hsu \& Brent 1998, Brent 2000, Bassett et al. 2007). As an example, studies using knockout and knockin mouse models have shown that TR $\beta$ is involved in mediating the $\mathrm{T}_{3}$ effects on liver metabolism such as reducing plasma cholesterol and triglycerides (Sadow et al. 2003, Fugier et al. 2006, Shin et al. 2006).

Thus, it makes perfect logic to use thyroid hormone analogs capable of tissue specificity either by selective 
uptake and/or by selective binding to the two TR isoforms (Chiellini et al. 1998, Ocasio \& Scanlan 2006). Activation of TR $\beta$ with a selective thyroid hormone analog (GC-1 compound) in rats results in the induction of UCP1 gene, while only minimally mediating synergism between thyroid hormone and the sympathetic nervous system (Ribeiro et al. 2001). In fact, the use of GC-1 or other TR $\beta$-selective agonists in rodents and primates has recently been shown to increase energy expenditure, decrease fat mass and plasma levels of cholesterol (Grover et al. 2004), while sparing the heart (Trost et al. 2000) and the skeletal system (Freitas et al. 2003). Also, in the ob/ob mouse model, the administration of different TR $\beta$ agonists improves glucose homeostasis (Bryzgalova et al. 2008). It is still not clear, however, how much of the effects of these molecules is due to TR selectivity as opposed to liver-specific uptake (Trost et al. 2000).

In the present study, we tested the hypothesis that chronic TR $\beta$ activation minimizes the metabolic consequences of feeding a high-fat diet. To such end, we used GC-24, a second generation TR $\beta$-selective molecule, which binds to TR $\beta$ with 40-fold higher affinity than TR $\alpha$ (Borngraeber et al. 2003, Miyabara et al. 2005). Our results indicate that the use of GC-24 prevents much of the metabolic alterations associated with feeding a high-fat diet, while not affecting the overall body and cardiac weights. Notably, changes in gene expression triggered by GC-24 were primarily detected in the brown adipose tissue (BAT), while only minimally affecting liver, skeletal muscle, and white adipose tissue.

\section{Materials and Methods}

\section{Drugs and reagents}

All drugs and reagents were purchased from Sigma Chemical Co. unless otherwise specified. GC-24 was kindly provided by Dr Thomas Scanlan.

\section{Animals and treatments}

Male Wistar rats weighing 150-200 g, were purchased from University of Sao Paulo Medical School (FMUSP, Sao Paulo, Brazil) and maintained on a $12 \mathrm{~h}$ light: $12 \mathrm{~h}$ darkness cycle at $25{ }^{\circ} \mathrm{C}$ with food and water ad libitum.

In one set of experiments, animals were fed either chow $(\sim 1.8 \mathrm{kcal} / \mathrm{g})$ or high-fat diet $(\sim 4.5 \mathrm{kcal} / \mathrm{g})$, consisting of $42 \%$ carbohydrate, $24 \%$ proteins, and $23 \%$ fat. After 10 days on the high-fat diet, the animals were started on a treatment with $\mathrm{T}_{3}(30 \mathrm{ng} / \mathrm{g}$ body weight $(\mathrm{BW})$ per day) or equimolar doses of GC-24 (17 ng/g BW per day) for 3 weeks. Administration was via daily i.p. injections. At the end of the experimental period, animals were studied for resting metabolic rate (RMR), glucose tolerance test (GTT), and insulin tolerance test (ITT). Animals were subsequently killed by exsanguinations under urethane anesthesia, and blood processed for plasma isolation and tissues samples were collected and immediately frozen for further analyses. Carcasses were frozen at $-80{ }^{\circ} \mathrm{C}$ for further processing.

On a second set of experiments, animals fed chow diet were treated with $\mathrm{T}_{3}(15 \mathrm{ng} / \mathrm{g} \mathrm{BW}$ per day) or equimolar doses of GC-24 (8.5 ng/g BW per day) for 45 days. Administration was via daily i.p. or s.c. injections. At the end of experimental period, animals were killed by exsanguinations under urethane anesthesia, and blood processed for plasma cholesterol determination.

\section{Oxygen consumption}

RMR was estimated by measuring oxygen consumption $\left(\mathrm{VO}_{2}\right)$ in an open circuit respirometer system (O2-10, Sable System, Las Vegas, NV, USA) as previously described (Withers 1977, Curcio et al. 1999). The experiments were carried out over a period of $30 \mathrm{~min}$ in the afternoon $(1400-1800 \mathrm{~h})$ at room temperature $\left(25^{\circ} \mathrm{C}\right)$ in animals fed ad libitum. Animals were maintained in their normal experimental conditions until immediately before the measurements. The data were collected and analyzed by the Sable Systems software. The results are expressed as milliliters of $\mathrm{O}_{2} / \mathrm{min}$ per $\mathrm{g} \mathrm{BW}$.

\section{Glucose tolerance test}

Animals were fasted overnight, and glucose $(2 \mathrm{~g} / \mathrm{kg})$ was administered by i.p. injection between 0900 and $1000 \mathrm{~h}$. Blood samples were collected from the tail at various times after the glucose load, as indicated, and glycemia was immediately determined on a glucose analyzer (LifeScan, Inc., Milipitas, CA, USA).

\section{Insulin tolerance test}

Food was removed $6 \mathrm{~h}$ before the experiment, which was carried out between 1400 and 1500 h. Blood samples were collected from the tail at various times after insulin $(0.5 \mathrm{U} / \mathrm{kg})$ was administered by i.p. injection, as indicated, and glucose serum levels determined immediately using a glucose analyzer.

\section{Blood chemistry}

Plasma cholesterol and triglycerides were assessed by colorimetric method using a commercial kit (Roche Molecular Biochemicals). Plasma NEFA was assessed by colorimetric method using a commercial kit (WACO NEFA C kit; Wako Chemical Industries USA, Inc., Richmond, VA, USA). The plasma concentrations of tumour necrosis factor $\alpha$ (TNF $\alpha$ ) and interleukin-6 (IL6) were measured by commercial ELISA kits (TNF $\alpha$, IL-6, R\&D System, 


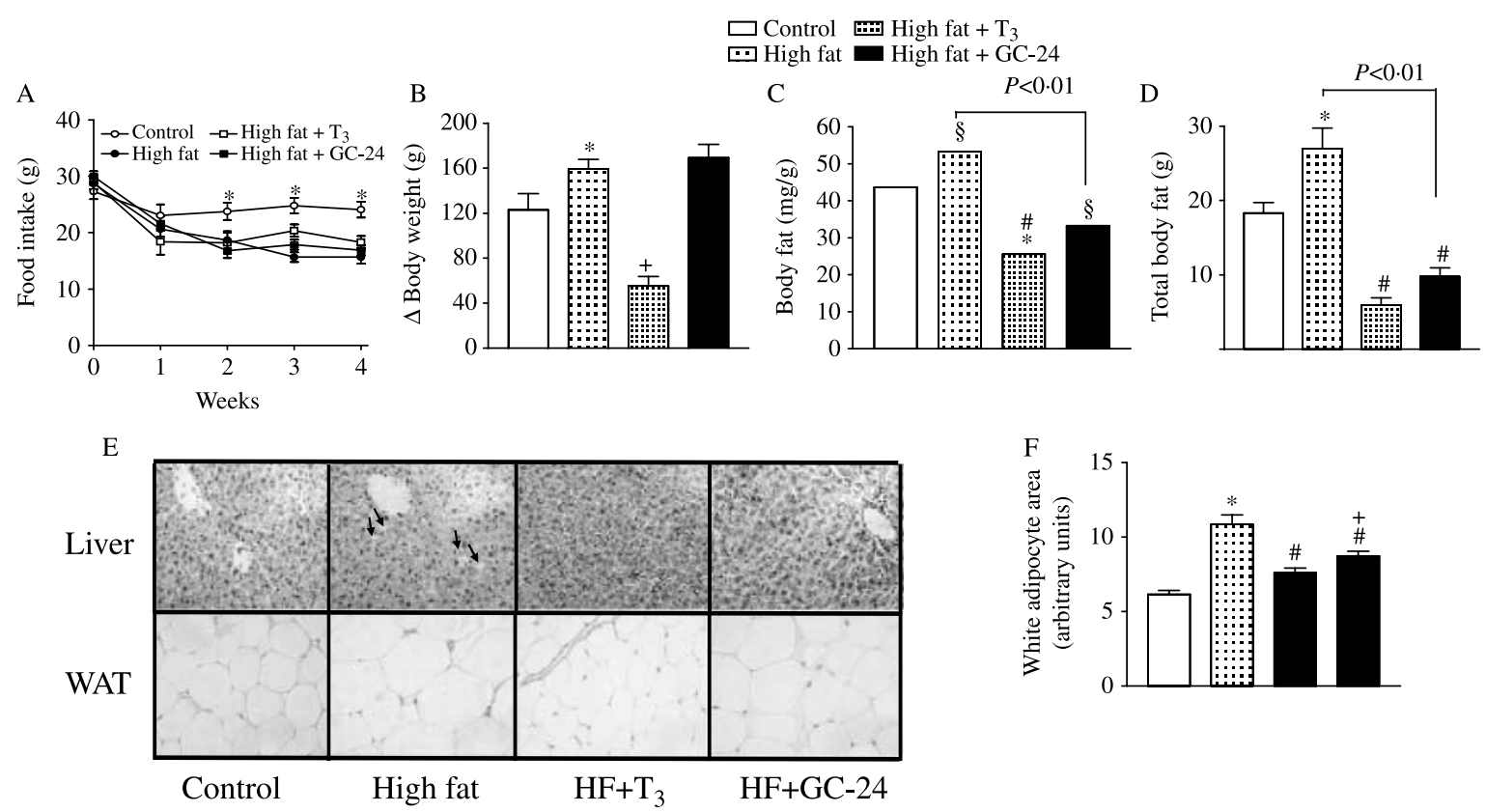

Figure 1 Effects of GC-24 on body weight and composition. Rats were placed on a high-fat diet for 4 weeks and treated with of $\mathrm{T}_{3} 10 \times(30 \mathrm{ng} / \mathrm{g}$ BW per day) or GC-24 in equimolar dosage. (A) Food intake; ${ }^{*} P<0 \cdot 005$ versus other groups; (B) total body weight gain; $* P<0 \cdot 001$ versus control; ${ }^{+} P<0.001$ versus high fat; (C) body fat content; ${ }^{*} P<0.05$ versus control; ${ }^{+} P<0.001$ versus high fat; (D) total body fat; $* P<0 \cdot 001$ versus control, ${ }^{\#} P<0.001$ versus high fat; (E) sections of epididymal adipose tissue and liver stained by H-E; magnification is $200 \times$; (F) estimated individual adipocyte area; 40 cells for each group were analyzed. All entries are mean \pm s.E.M.

Belgium), according to the manufacturer's instructions (Yu et al. 2007). The protein concentration was determined by the method of Bradford (1976).

\section{Liver chemistry}

Lipids were extracted from the liver by disrupting $\sim 200 \mathrm{mg}$ frozen liver samples in $2 \mathrm{ml}$ isopropyl alcohol with a Potter Elvehjem homogenizer (model MA 099; Marconi, Piracicaba, SP, Brazil). Homogenates were maintained at $37^{\circ} \mathrm{C}$ for $30 \mathrm{~min}$ and then at $4{ }^{\circ} \mathrm{C}$ overnight. Total cholesterol and triacylglycerols were determined by enzymatic methods
(Roche Diagnóstica) in a supernatant aliquot. Protein concentration was determined according to the method of Lowry et al. (1951) in liver samples $(200 \mathrm{mg})$ previously homogenized in $4 \mathrm{ml}$ of water.

\section{$m R N A$ analysis}

Total RNA of liver, epididymal white fat and interscapular BAT was extracted using the Trizol (Life Technologies Inc.), according to the manufacturer's instructions, and quantified by spectrophotometry. For the reverse transcriptase reaction, $0 \cdot 8 \mu \mathrm{g}$ of total RNA was used in the SuperScrit First-Strand

Table 1 Effects of tri-iodothyronine $\left(T_{3}\right)(10 \times)$ or equimolar doses of GC-24 in animals placed on a high-fat diet. Values indicated as mean \pm S.E.M.

\begin{tabular}{|c|c|c|c|c|}
\hline & Control & HF & $\mathbf{H F}+\mathbf{T}_{3}$ & $\mathrm{HF}+\mathrm{GC}-24$ \\
\hline Fasting glucose $(\mathrm{mg} / \mathrm{dl})$ & $65 \pm 7 \cdot 8$ & $86 \pm 5^{*}$ & $90 \pm 5^{*}$ & $97 \pm 7^{*}$ \\
\hline Cholesterol (mg/dl) & $82 \pm 8$ & $125 \pm 21 *$ & $65 \pm 5^{\S}$ & $99 \pm 7 \cdot 5$ \\
\hline $\operatorname{NEFA}(\mathrm{mg} / \mathrm{dl})$ & $6 \pm 0 \cdot 3$ & $12 \pm 0 \cdot 5^{+}$ & $14 \pm 0 \cdot 3^{\ddagger}$ & $14 \pm 1 \cdot 6^{\neq}$ \\
\hline IL6 & $44 \cdot 6 \pm 3 \cdot 6$ & $61 \pm 3 \cdot 8^{* \pi}$ & $47 \pm 3 \cdot 1^{\S}$ & $59 \pm 2 \cdot 7^{*}$ \\
\hline TNF $\alpha$ & $8 \cdot 1 \pm 1 \cdot 1$ & $10 \pm 0 \cdot 5^{*}$ & $9 \pm 0 \cdot 8^{\ddagger}$ & $10 \pm 0 \cdot 9^{\| \prime}$ \\
\hline $\mathrm{T}_{4}(\mu \mathrm{g} / \mathrm{dl})$ & $3 \cdot 8 \pm 0 \cdot 4$ & $4 \cdot 8 \pm 1 \cdot 9$ & $<1$ & $3 \cdot 1 \pm 0 \cdot 7$ \\
\hline
\end{tabular}

${ }^{*} P<0.01$ versus control; ${ }^{+} P<0 \cdot 001$ versus control; ${ }^{\ddagger} P<0 \cdot 05$ versus high fat $(\mathrm{HF}) ;{ }^{\circledR} P<0.01$ versus high fat; $" P<0 \cdot 05$ versus control. High fat $+\mathrm{T}_{3}\left(\mathrm{HF}+\mathrm{T}_{3}\right)$; high fat + GC-24 (HF+ GC-24); ${ }^{\top} P<0 \cdot 05$. 
Table 2 Effects of tri-iodothyronine $\left(\mathrm{T}_{3}\right)(10 \times)$ or equimolar doses of GC-24 in animals placed on a high-fat diet. Values indicated as mean \pm S.E.M.

\begin{tabular}{|c|c|c|c|c|}
\hline & Control & HF & $\mathrm{HF}+\mathrm{T}_{3}$ & $\mathrm{HF}+\mathrm{GC}-24$ \\
\hline $\begin{array}{l}\text { Total water } \\
(\mathrm{ml} / \mathrm{kg} \mathrm{BW})\end{array}$ & $274 \pm 13$ & $260 \pm 23$ & $236 \pm 7^{*}$ & $274 \pm 19$ \\
\hline $\begin{array}{l}\text { Lean body } \\
\text { mass }(\%)\end{array}$ & $85 \pm 2 \cdot 2$ & $79 \pm 9$ & $91 \pm 3 \cdot 7$ & $88 \pm 2 \cdot 4$ \\
\hline
\end{tabular}

$* P<0 \cdot 05$ versus $\mathrm{HF}$ and $P<0 \cdot 05$ versus $\mathrm{HG}+\mathrm{GC}-24$.

Synthesis System for real-time (RT)-PCR (Invitrogen) on Robocycler thermocycler (Stratagene, La Jolla CA, USA). About 120 ng cDNA was used for amplification. Quantitative RT-PCR (RT-qPCR) was performed using IQ SYBR Green PCR kit (BioRad) on iCycler thermal cycler machine (Bio-Rad). Primers were designed with the help of Beacon Designer 3.0 (Premiere Biosoft Intl., Palo Alto, CA, USA), and the housekeeping gene cyclophilin A used as internal reference. Primer sequences are available upon request. The cycle conditions were: $5 \mathrm{~min}$ at $94{ }^{\circ} \mathrm{C}$ (Hot start); $30 \mathrm{~s}$ at $94^{\circ} \mathrm{C}, 30 \mathrm{~s}$ at $58^{\circ} \mathrm{C}$, and $45 \mathrm{~s}$ at $72^{\circ} \mathrm{C}$ for 50 cycles followed by the melting curve protocol to verify the specificity of amplicon generation. Gene expression was determined by $\Delta \Delta C_{t}$, and all values were expressed using cyclophilin A mRNA as an internal control (Christoffolete et al. 2004).

RIA Total thyroxine $\left(\mathrm{T}_{4}\right)$ and $\mathrm{T}_{3}$ serum levels were measured in $25 \mu \mathrm{l}$ serum samples in duplicate using specific RIA (Coat-A-Count $\mathrm{T}_{3}$ Uptake Test Kit and Coat-A-Count $\mathrm{T}_{4}$ Uptake Test Kit; DPC, Los Angeles, CA, USA).

\section{Fat mass measurement}

Carcasses were thawed overnight at $4{ }^{\circ} \mathrm{C}$, weighed, chopped in small pieces and then, using a motorized blender (Kinematica AG, Lucerne Switzerland), thoroughly homogenized in a volume of distilled water that equals the weight of the carcasses. Aliquots of homogenates were used for measurements of water, protein, and fat content. The water content was calculated as the weight variance after $24 \mathrm{~h}$ at $100{ }^{\circ} \mathrm{C}$, as previously described (Bertin et al. 1998). Fat content was determined as previously described (Folch et al. 1957, Hartsook \& Hershberger 1963, Azain et al. 1995), after lipid was extracted with a 2:1 chloroform:methanol solution. The lipid-containing chloroform layer was separated and dried to constant weight. The protein content was determined as described by Bradford (1976).

\section{Histological examination}

After careful dissection, tissues were immersed in buffered formol solution and fixed for $24 \mathrm{~h}$. Paraffin-embedded tissues were sectioned and processed as described (Kerr et al. 1995). Analyses were performed after hematoxylin-eosin staining. The area of the white adipocytes was estimated by analyzing pictures taken at $100 \times$ magnification. Picture printouts were cut, and the area of at least 40 adipocytes per animal was estimated.

\section{Statistical analysis}

Results are expressed as the mean \pm s.E.M. throughout the text, tables, and figures. Multiple comparisons were performed by one-way ANOVA, followed by StudentNewman-Keuls test.
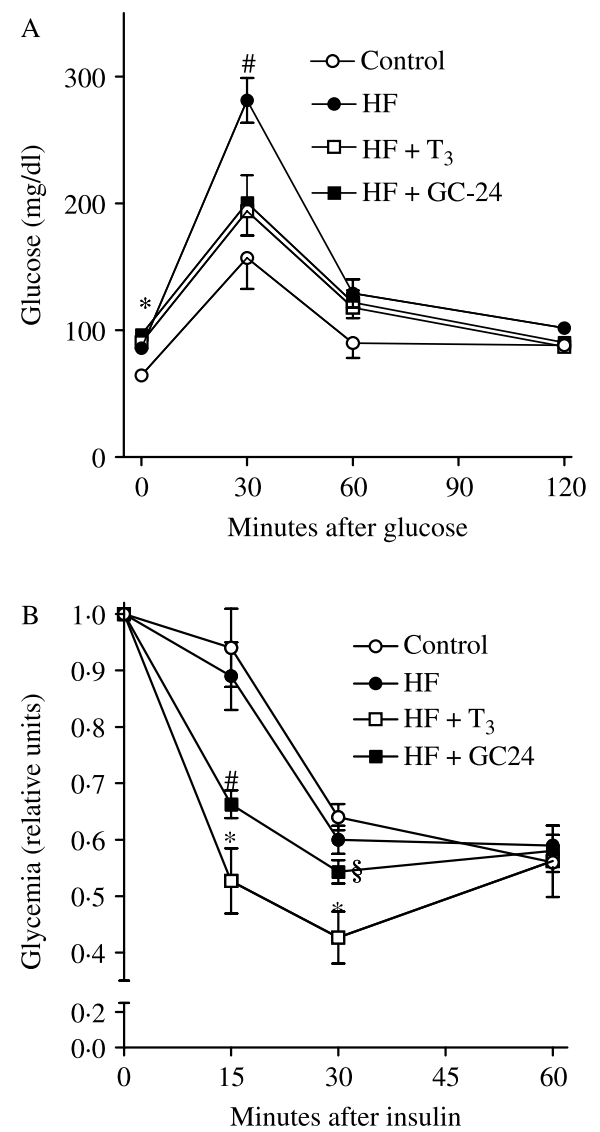

Figure 2 Effects of GC-24 on GTT and ITT. Rats were placed on a high-fat diet for 4 weeks and treated with of $\mathrm{T}_{3} 10 \times(30 \mathrm{ng} / \mathrm{g} \mathrm{BW}$ per day) or GC-24 in equimolar dosage. (A) Glycemic levels $(\mathrm{mg} / \mathrm{dl})$. After fasting overnight, animals were injected with $2 \mathrm{~g} / \mathrm{kg}$ of glucose, and plasma glucose levels were measured in $30 \mathrm{~min}$ intervals via tail bleeding; ${ }^{\sharp} P<0.01$ versus all other groups; $* P<0 \cdot 01$ versus other groups. (B) Glycemic levels (in arbitrary units). After fasting for $6 \mathrm{~h}$, animals were injected with $0.5 \mathrm{U} / \mathrm{kg}$ of insulin and glucose blood levels were measured in $15 \mathrm{~min}$ intervals via tail bleeding; ${ }^{*} P<0 \cdot 001$ versus control and high fat; ${ }^{\sharp} P<0 \cdot 05$ versus control and high fat; ${ }^{\S} P<0.001$ versus high fat $+T_{3}$. Entries are mean \pm S.E.M.; $n=5$. 

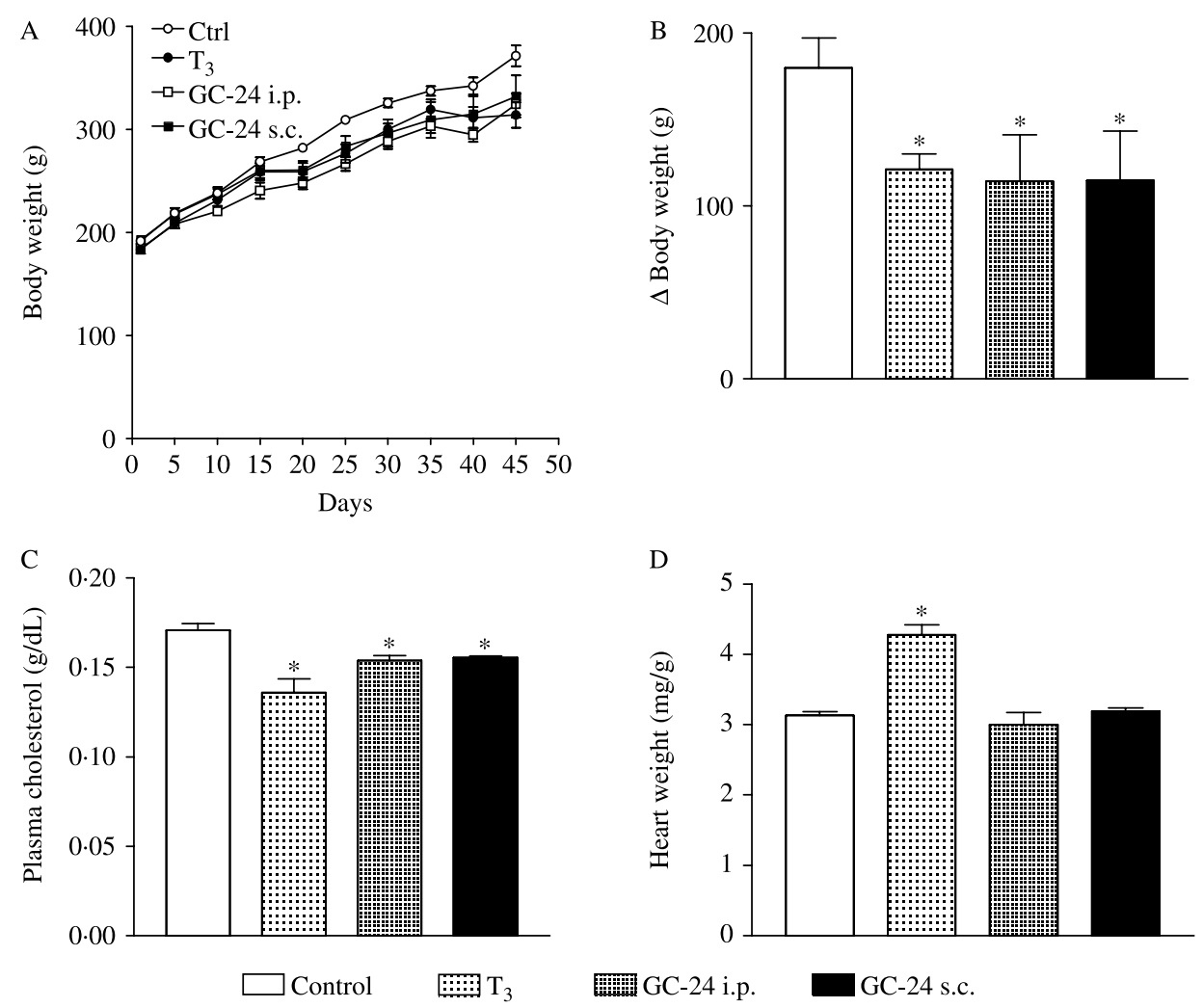

Figure 3 Effects of GC-24 on body weight, cholesterol levels, and heart weight. Rats were placed on a chow diet and treated with of $\mathrm{T}_{3} 5 \times(15 \mathrm{ng} / \mathrm{g}$ BW per day) or GC-24 in equimolar dose via i.p. or s.c. daily injections. (A) Total body weight. (B) Body weight gain; ${ }^{*} P<0 \cdot 01$ versus control. (C) Plasma cholesterol levels; ${ }^{*} P<0.001$ versus control and ${ }^{+} P<0.05$ versus control. (D) Heart weight; ${ }^{*} P<0.001$ versus other groups. Entries are mean \pm S.E.M.; $n=6$.

\section{Results}

Feeding a high-fat diet resulted in $\sim 30 \%$ compensatory reduction in food intake as early as the first experimental week (Fig. 1A). Despite this, at the end of the 4-week period, the animals on the high-fat diet gained significantly more BW ( 30\%; Fig. 1B), and accumulated more fat in absolute and relative terms $(\sim 22$ and $\sim 50 \%$; Fig. $1 C$ and D). Concomitant treatment with GC-24 $(1 \cdot 7 \mu \mathrm{g} / 100 \mathrm{~g} \mathrm{BW}$ per day) did not affect serum $\mathrm{T}_{3}$ levels or the $\mathrm{T}_{3} / \mathrm{T}_{4}$ ratio in the serum (Table 1). At the same time, it did reduce body fat to levels below those found in animals fed chow diet $(-\sim 23 \%$; Fig. 1C and D), but did not affect total body water nor prevent the accelerated increase in BW (Fig. 1B; Table 2). High-fat feeding caused visible fat deposition in liver, which was prevented by treatment with GC-24 (Fig. 1E). A similar, but much less dramatic, pattern was observed with the size of the fat cells (Fig. 1E and F). The estimated adipocyte area was doubled with the high-fat diet, while treatment with GC-24 only partially reduced it, to levels still above controls $(\sim 40 \%$; Fig. 1E and F). Notably, this effect of GC-24 took place without changes in food ingestion (Fig. 1A) or cardiac weight
(Table 1), a sensitive index of thyroid hormone effects in the heart. As a reference, other animals were placed on a high-fat diet and treated with equimolar amounts of $\mathrm{T}_{3}(3 \mu \mathrm{g} / 100 \mathrm{~g}$ $\mathrm{BW}$ per day), in a dosage equivalent to 10 times the daily $\mathrm{T}_{3}$ replacement dose. Such animals gained less BW $(-\sim 65 \%)$, had less total fat content $(-\sim 70 \%)$, less total body water ( $\sim 15 \%$; Table 2$)$, while at the same time exhibited cardiac hypertrophy $(\sim 23 \%$; Table 1$)$.

Rats placed on a high-fat diet developed the expected fasting hyperglycemia ( $86 \mathrm{vs} 65 \mathrm{mg} / \mathrm{dl}$ ) and glucose intolerance with a 30-min peak after glucose load reaching $281 \mathrm{mg} / \mathrm{dl}$ (Fig. 2A); at least in this setting, these animals did not exhibit resistance to insulin (Fig. 2B). Whereas the GC-24-treated animals still had significant fasting hyperglycemia $(96.5 \mathrm{mg} / \mathrm{dl})$, the maximum 30-min glucose peak was $\sim 30 \%$ reduced (Fig. 2A). Insulin sensitivity was increased at early time points after insulin administration in GC-24-treated animals (Fig. 2B). Likewise, treatment with $\mathrm{T}_{3}$ mimicked the effects of GC-24 (Fig. 2A and B).

Animals placed on a high-fat diet exhibited significantly higher plasma levels of triglycerides, total cholesterol, NEFA, and IL6 (Table 1). At the same time, treatment with GC-24 

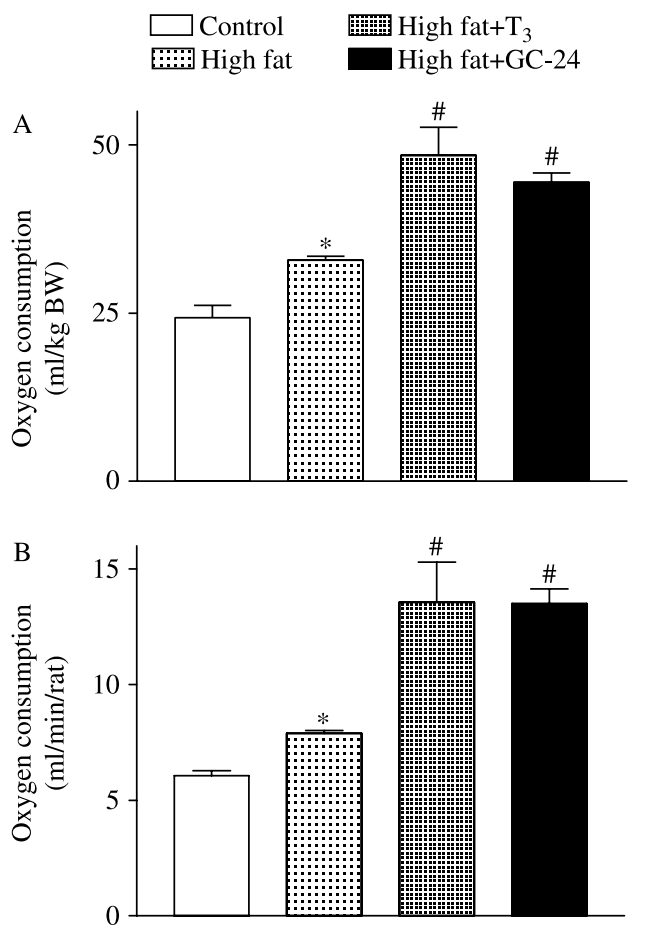

Figure 4 Effects of GC-24 on resting metabolic rate (RMR). Rats were placed on a high-fat diet for 4 weeks and treated with of $\mathrm{T}_{3} 10 \times(30 \mathrm{ng} / \mathrm{g} \mathrm{BW}$ per day) or GC-24 in equimolar dosage. (A) Normalized RMR (ml/min per kg BW); ${ }^{*} P<0.001$ versus control; ${ }^{\sharp} P<0 \cdot 01$ versus high fat. (B) Total RMR (ml/min per rat); ${ }^{*} P<0.001$ versus control; ${ }^{*} P<0.01$ versus figh fat. Entries are mean \pm S.E.M.; $n=6$.

normalized plasma triglycerides concentration but failed to prevent the increase in NEFA and IL-6 (Table 1). Plasma cholesterol concentration was only partially normalized by GC-24 (Table 1). In addition, liver total cholesterol levels, which were increased during high-fat feeding, were not at all affected by treatment with GC-24 (Table 1). Notably, treatment with $T_{3}$ had very similar metabolic effects as GC-24, except that it did prevent the increase in plasma and liver cholesterol associated with the high-fat diet (Table 1).

Because TR $\beta$-selective agonists were shown to reduce cholesterol levels in a number of different settings (Trost et al. 2000, Grover et al. 2003, 2004, 2005), we tested whether the failure to do so in the present study was explained by the fact that the animals were placed on a high-fat diet. Route of administration (s.c. versus i.p.) was also evaluated because of the possibility that the metabolic effects of $T_{3}$ and/or TR $\beta$-selective agonists depend on a first-pass effect on the liver after i.p. administration. Thus, rats kept on a chow diet were treated with GC-24 $(0.85 \mu \mathrm{g} / 100 \mathrm{~g} \mathrm{BW}$ per day) for 45 days via i.p. or s.c. daily injections. Remarkably, regardless of the administration route, GC-24 administration significantly decreased BW gain $(-\sim 37 \%$; Fig. $3 \mathrm{~A}$ and $\mathrm{B})$ and plasma cholesterol levels (- 10\%; Fig. 3C), without affecting heart weight (Fig. 3D). Again, treatment with equimolar amounts of $\mathrm{T}_{3}$ (i.p.) produced similar effects, while increasing cardiac weight $(\sim 36 \%$; Fig. 3A-D).

RMR was significantly increased during high-fat feeding, $\sim 25 \%$ (Fig. 4A). This increase was observed even when oxygen consumption was corrected by total body mass (Fig. 4B). Notably, a further pronounced increase in RMR was observed in the GC-24-treated animals, which almost doubled the rates observed in the control animals (Fig. 4A and $\mathrm{B}$ ). Likewise, $\mathrm{T}_{3}$ treatment also resulted in a substantial elevation in the RMR (Fig. 4A and B).

To gain insight into the mechanism by which GC-24 triggers such a wide array of metabolic effects, we used RT-qPCR for measuring the expression of multiple key metabolic genes and found that GC-24 acts predominantly in the BAT (Fig. 5A). While feeding a high-fat diet per se promoted marked changes in BAT gene expression (Fig. 5A), treatment with GC-24 stimulated even further the expression of several genes, such as ACC- 1 (2·3-fold), CPTI $(5 \cdot 6$-fold), and SD (11-fold; Fig. 5B). The effects of $\mathrm{T}_{3}$ in the BATwere less pronounced and restricted to ACC (1.4-fold; Fig. 5B). These changes in gene expression correlated with BAT activation as seen in Fig. 5E. Notably, liver, gastrocnemius, and white adipose tissue of animals fed a high-fat diet responded poorly to treatment with GC-24 or $\mathrm{T}_{3}$. There was a significant stimulation of gastrocnemius PGC- $1 \alpha$ (threefold) and CPT1 (twofold) expression, with no major changes in white adipose tissue (Fig. 5). In the liver, only the type 1 iodothyronine deiodinase gene (Dio1), a known $\mathrm{T}_{3}$-resposive gene, was further stimulated by GC-24 (1·4-fold; Fig. 5A).

\section{Discussion}

Recent studies indicate that the administration of TR $\beta$-selective agonists has beneficial metabolic effects, e.g. increase in energy expenditure, while lowering serum cholesterol and triglycerides (Trost et al. 2000, Grover et al. 2004, Johansson et al. 2005, Villicev et al. 2007). In the present study, we expanded these findings and have shown that the administration of GC-24, a novel and even more selective $\operatorname{TR} \beta$ agonist, prevented some of the metabolic abnormalities associated with feeding a high-fat diet, namely increase in fat mass (Fig. 1C and D), glucose intolerance (Fig. 2A), and hypertriglyceridemia (Table 1), while it did improve sensitivity to insulin (Fig. 2B). At the same time, other parameters that were elevated by high-fat feeding were only partially or not affected at all by treatment with GC-24, such as IL6, NEFA, and cholesterol levels (Table 1).

It is remarkable that in rats fed a high-fat diet, a substantial improvement in key metabolic parameters, i.e. plasma TG, body fat, glucose tolerance, and insulin sensitivity, is achieved with GC-24 treatment without affecting cardiac weight. One consideration is that GC-24 activates a number of wellknown $\mathrm{T}_{3}$-responsive pathways, e.g. lipolysis, $\beta$-oxidation, which combined would improve the overall metabolic status 
A

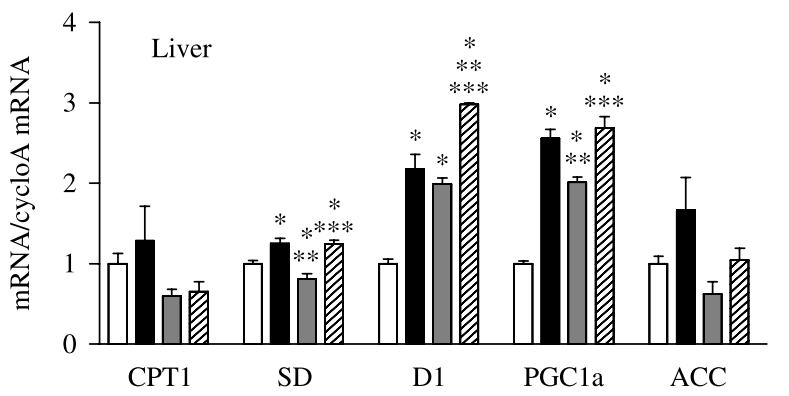

$\mathrm{C}$

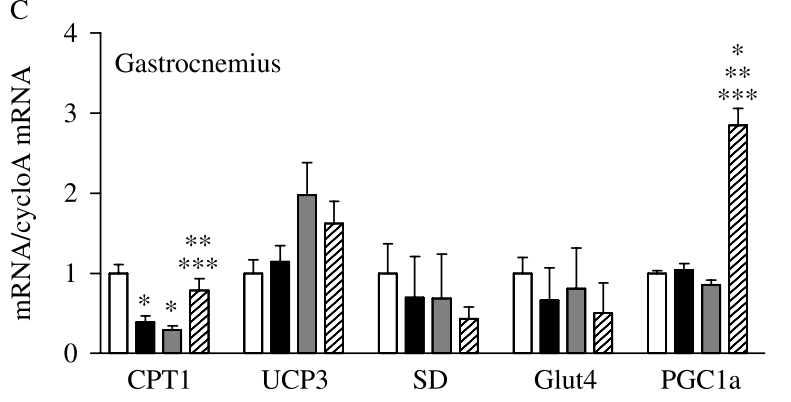

B

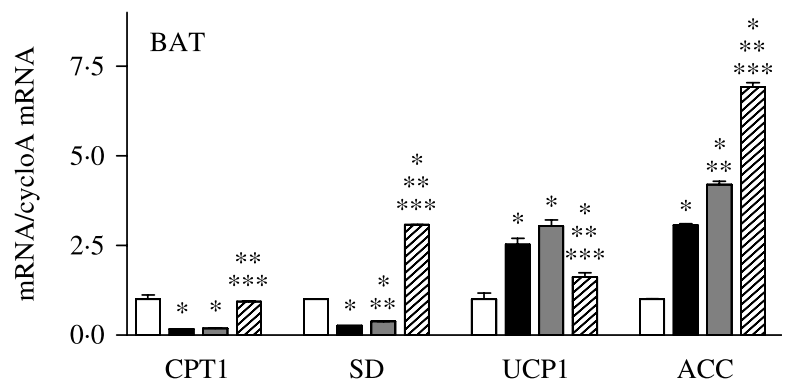

$\mathrm{D}$

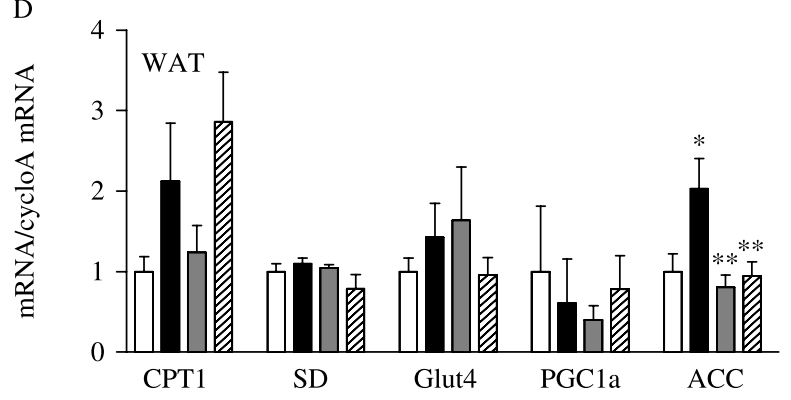

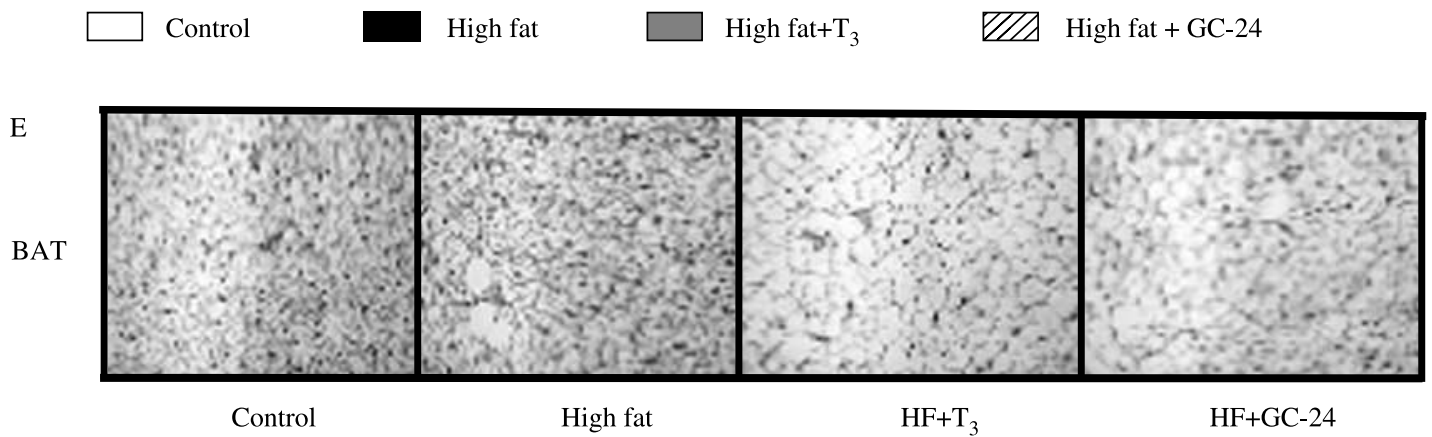

Figure 5 GC-24 increases the expression of key metabolic genes and BAT histology. Gene expression profile of animals placed on a high-fat diet for 4 weeks and treated with of $\mathrm{T}_{3} 10 \times(30 \mathrm{ng} / \mathrm{g} \mathrm{BW}$ per day) or GC-24 in equimolar dosage, in liver (A), BAT (B), gastrocnemius (C), and white adipocyte tissue (D). Sections of brown adipose tissue stained by $\mathrm{H}-\mathrm{E}$; magnification is $200 \times$. Tissue mRNA levels were measured using real-time $\mathrm{qPCR}$ technique, and data is expressed relative to control group. Where ${ }^{*} P<0.05$ versus control; ${ }^{* *} P<0.005$ versus high fat;

$* * * P<0 \cdot 05$ versus high fat treated with $\mathrm{T}_{3}$. Entries are mean \pm s.E.M.; $n=3$.

of these animals. For example, it has been shown that $\mathrm{T}_{3}$ administration improves glucose tolerance in $o b / o b$ mice via TR $\beta$ activation (Bryzgalova et al. 2008), while it up regulates GLUT4 expression (Casla et al. 1990, Torrance et al. 1997). At the same time, a more comprehensive explanation could simply be that GC-24 markedly accelerates the RMR by mimicking $\mathrm{T}_{3}$ actions (Fig. 4). An accelerated RMR would balance the increased energy intake, limit fat accumulation, and improve glucose homeostasis. This second hypothesis is supported by previous findings that a major contribution of TR $\beta$-mediating effects in through energy expenditure (Grover et al. 2004, 2005, Villicev et al. 2007).

Given the predominance of TR $\beta$ in the liver (Schwartz et al. 1992) and the substantial effects of TR $\beta$-selective agonists as cholesterol-lowering agents, it is assumed that the bulk of the effects of these molecules take place in the liver (Grover et al. 2004, Erion et al. 2007). However, our analysis of gene expression in liver, skeletal muscle, white fat and BAT indicates that the latter was predominantly affected. In the BAT, there was a significant increase in $C p t 1, S d$, and Acc 1 gene expression by GC-24, indicating the activation of this tissue (Fig. 5). In turn, this would explain the increase in metabolic rate by GC-24.

At the same time, a number of other metabolic parameters were not restored or affected by GC-24, namely increased IL6 and NEFA plasma concentrations, fasting hyperglycemia as well as hypercholesterolemia and liver cholesterol content. Persistently elevated IL6 and NEFA indicate that despite 
improvements, these animals remain metabolically challenged due to the elevated fat intake. Fasting hyperglycemia remains despite increased insulin sensitivity most likely as a result of higher hepatic glucose production via stimulation of PEPCk gene expression (Loose et al. 1985, Klieverik et al. 2008).

The suboptimal effects of GC-24 on cholesterol metabolism are particularly notable. Thus, treatment with GC-24 only minimized, but not normalized, the increase in plasma cholesterol levels resulting from the high-fat feeding, while liver cholesterol content remained high (Table 1). Because TR $\beta$-selective agonists were shown to be effective cholesterol-lowering agents (Trost et al. 2000, Grover et al. 2003, 2004, Johansson et al. 2005, Miyabara et al. 2005), one explanation is that GC-24/ $\mathrm{T}_{3}$ signaling could be decreased in the liver of high-fat fed animals (Crunkhorn \& Patti 2008). This is supported by the observation that in rats kept on chow diet, GC-24 did reduce plasma cholesterol (Fig. 3C). However, the liver expression of Dio1, $S d$, and $\operatorname{Pgc1} \alpha$ was all increased by GC-24 in high-fat fed animals, indicating that $\mathrm{GC}-24 / \mathrm{T}_{3}$ signaling seems to be preserved in these animals. In addition, in such animals, both plasma cholesterol and liver cholesterol concentrations were normalized by treatment with equimolar doses of $\mathrm{T}_{3}$ (Table 1). While it is not clear what the mechanism interfering with GC-24 actions in liver is, reduced effectiveness of this TR $\beta$-selective agonist as a cholesterol-lowering agent when combined with a high-fat diet is an important finding, which could have substantial impact on their planned therapeutic utilization.

Most studies with TR $\beta$-selective agonists so far involved either oral gavage or i.p. administration. Because both routes involve a first passage through the liver, it has been suggested that this anatomic aspect contributes to the liver selectivity of these compounds. Our data, however, indicate that this is not the case given that animals kept on chow diet while receiving s.c. injections of GC-24 had their plasma cholesterol levels lowered (-10×\%) and gained less BW (- 37\%; Fig. 3).

In conclusion, the present studies show that administration of a highly TR $\beta$-selective agonist to rats during feeding with a high-fat diet prevented a number of metabolic alterations typical of this condition such as increase in fat mass (Fig. 1C and D), glucose intolerance (Fig. 2A), and hypertriglyceridemia (Table 1). The overall mechanism seems to be acceleration in the RMR, which takes place in BAT. However, GC-24 treatment did not restore hypercholesterolemia, increased hepatic cholesterol content, elevated NEFA and IL6 levels, indicating that these metabolic pathways are less sensitive to activation of TR $\beta$ signaling during feeding with a high-fat diet. These findings should have important repercussions to the potential usage of TR $\beta$-selective agonists as cholesterol-lowering agents.

\section{Declaration of interest}

We declare that there is no conflict of interest that could be perceived as prejudicing the impartiality of the research here reported.

\section{Funding}

This work was supported by grants from MackPesquisa and FAPESP (05/56477-3 to M O R), NIH (DK65055 to A C B), and PIBIC (R N J).

\section{References}

Abrams JJ, Grundy SM \& Ginsberg H 1981 Metabolism of plasma triglycerides in hypothyroidism and hyperthyroidism in man. Journal of Lipid Research 22 307-322.

Azain MJ, Roberts TJ, Martin RJ \& Kasser TR 1995 Comparison of daily versus continuous administration of somatotropin on growth rate, feed intake, and body composition in intact female rats. Journal of Animal Science 73 1019-1029.

Bassett JH, Nordstrom K, Boyde A, Howell PG, Kelly S, Vennstrom B \& Williams GR 2007 Thyroid status during skeletal development determines adult bone structure and mineralization. Molecular Endocrinology 21 1893-1904.

Bertin E, Ruiz JC, Mourot J, Peiniau P \& Portha B 1998 Evaluation of dual-energy X-ray absorptiometry for body-composition assessment in rats. Journal of Nutrition 128 1550-1554.

Borngraeber S, Budny MJ, Chiellini G, Cunha-Lima ST, Togashi M, Webb P, Baxter JD, Scanlan TS \& Fletterick RJ 2003 Ligand selectivity by seeking hydrophobicity in thyroid hormone receptor. PNAS $\mathbf{1 0 0}$ 15358-15363.

Bradford MM 1976 A rapid and sensitive method for the quantitation of microgram quantities of protein utilizing the principle of protein-dye binding. Analytical Biochemistry 72 248-254.

Brent GA 2000 Tissue-specific actions of thyroid hormone: insights from animal models. Reviews in Endocrine \& Metabolic Disorders 1 27-33.

Bryzgalova G, Effendic S, Khan A, Rehnmark S, Barbounis P, Boulet J, Dong G, Singh R, Shapses S, Malm J et al. 2008 Anti-obesity, antidiabetic, and lipid lowering effects of the thyroid receptor beta subtype selective agonist KB-141. Journal of Steroid Biochemistry and Molecular Biology 111 262-267.

Casla A, Rovira A, Wells JA \& Dohm GL 1990 Increased glucose transporter (GLUT4) protein expression in hyperthyroidism. Biochemical and Biophysical Research Communications 171 182-188.

Chiellini G, Apriletti JW, Yoshihara HA, Baxter JD, Ribeiro RC \& Scanlan TS 1998 A high-affinity subtype-selective agonist ligand for the thyroid hormone receptor. Chemistry \& Biology 5 299-306.

Christoffolete MA, Linardi CC, de Jesus L, Ebina KN, Carvalho SD, Ribeiro MO, Rabelo R, Curcio C, Martins L, Kimura ET et al. 2004 Mice with targeted disruption of the Dio2 gene have cold-induced overexpression of the uncoupling protein 1 gene but fail to increase brown adipose tissue lipogenesis and adaptive thermogenesis. Diabetes $\mathbf{5 3}$ $577-584$.

Crunkhorn S \& Patti ME 2008 Links between thyroid hormone action, oxidative metabolism, and diabetes risk? Thyroid 18 227-237.

Curcio C, Lopes AM, Ribeiro MO, Francoso OA Jr, Carvalho SD, Lima FB, Bicudo JE \& Bianco AC 1999 Development of compensatory thermogenesis in response to overfeeding in hypothyroid rats. Endocrinology 140 3438-3443.

Erion MD, Cable EE, Ito BR, Jiang H, Fujitaki JM, Finn PD, Zhang BH, Hou J, Boyer SH, van Poelje PD et al. 2007 Targeting thyroid hormone receptor-beta agonists to the liver reduces cholesterol and triglycerides and improves the therapeutic index. PNAS 104 15490-15495.

Folch J, Lees M \& Sloane Stanley GH 1957 A simple method for the isolation and purification of total lipides from animal tissues. Journal of Biological Chemistry 226 497-509.

Freitas FR, Moriscot AS, Jorgetti V, Soares AG, Passarelli M, Scanlan TS, Brent GA, Bianco AC \& Gouveia CH 2003 Spared bone mass in rats treated with thyroid hormone receptor TR beta-selective compound GC-1. American Journal of Physiology. Endocrinology and Metabolism 285 E1135-E1141. 
Fugier C, Tousaint JJ, Prieur X, Plateroti M, Samarut J \& Delerive P 2006 The lipoprotein lipase inhibitor ANGPTL3 is negatively regulated by thyroid hormone. Journal of Biological Chemistry 281 11553-11559.

Galliford TM, Murphy E, Williams AJ, Bassett JH \& Williams GR 2005 Effects of thyroid status on bone metabolism: a primary role for thyroid stimulating hormone or thyroid hormone? Minerva Endocrinologica 30 237-246.

Grover GJ, Mellstrom K, Ye L, Malm J, Li YL, Bladh LG, Sleph PG, Smith MA, George R, Vennstrom B et al. 2003 Selective thyroid hormone receptor-beta activation: a strategy for reduction of weight, cholesterol, and lipoprotein (a) with reduced cardiovascular liability. PNAS 100 10067-10072.

Grover GJ, Egan DM, Sleph PG, Beehler BC, Chiellini G, Nguyen NH, Baxter JD \& Scanlan TS 2004 Effects of the thyroid hormone receptor agonist GC-1 on metabolic rate and cholesterol in rats and primates: selective actions relative to $3,5,3^{\prime}$-triiodo-L-thyronine. Endocrinology 145 1656-1661.

Grover GJ, Mellstrom K \& Malm J 2005 Development of the thyroid hormone receptor beta-subtype agonist KB-141: a strategy for body weight reduction and lipid lowering with minimal cardiac side effects. Cardiovascular Drug Reviews 23 133-148.

Hansson P, Valdemarsson S \& Nilsson-Ehle P 1983 Experimental hyperthyroidism in man: effects on plasma lipoproteins, lipoprotein lipase and hepatic lipase. Hormone and Metabolic Research 15 449-452.

Hartsook EW \& Hershberger TV 1963 A simplified method for sampling small animal carcasses for analyses. Proceedings of the Society for Experimental Biology and Medicine 113 973-977.

Hsu JH \& Brent GA 1998 Thyroid hormone receptor gene knockouts. Trends in Endocrinology and Metabolism 9 103-112.

Johansson L, Rudling M, Scanlan TS, Lundasen T, Webb P, Baxter J, Angelin B \& Parini P 2005 Selective thyroid receptor modulation by GC-1 reduces serum lipids and stimulates steps of reverse cholesterol transport in euthyroid mice. PNAS 102 10297-10302.

Kerr JF, Gobe GC, Winterford CM \& Harmon BV 1995 Anatomical methods in cell death. Methods in Cell Biology 46 1-27.

Klein I \& Ojamaa K 2001 Thyroid hormone and the cardiovascular system. New England Journal of Medicine 344 501-509.

Klieverik LP, Sauerwein HP, Ackermans MT, Boelen A, Kalsbeek A \& Fliers E 2008 Effects of thyrotoxicosis and selective hepatic autonomic denervation on hepatic glucose metabolism in rats. American Journal of Physiology. Endocrinology and Metabolism 294 E513-E520.

Klitgaard HM, Dirks HB Jr, Garlick WR \& Barker SB 1952 Protein-bound iodine in various tissues after injection of elemental iodine. Endocrinology $\mathbf{5 0}$ 170-173.

Loose DS, Cameron DK, Short HP \& Hanson RW 1985 Thyroid hormone regulates transcription of the gene for cytosolic phosphoenolpyruvate carboxykinase (GTP) in rat liver. Biochemistry 24 4509-4512.

Lowry OH, Rosebrough NJ, Farr AL \& Randall RJ 1951 Protein measurement with the folin phenol reagent. Journal of Biological Chemistry $193265-275$.

Miyabara EH, Aoki MS, Soares AG, Saltao RM, Vilicev CM, Passarelli M, Scanlan TS, Gouveia CH \& Moriscot AS 2005 Thyroid hormone receptorbeta-selective agonist GC-24 spares skeletal muscle type I to II fiber shift. Cell Tissue Research 321 233-241.
Murphy E \& Williams GR 2004 The thyroid and the skeleton. Clinical Endocrinology 61 285-298.

Ocasio CA \& Scanlan TS 2006 Design and characterization of a thyroid hormone receptor $\alpha(\mathrm{TR} \alpha)$-specific agonist. ACS Chemical Biology 1 585-593.

Placidi GP, Boldrini M, Patronelli A, Fiore E, Chiovato L, Perugi G \& Marazziti D 1998 Prevalence of psychiatric disorders in thyroid diseased patients. Neuropsychobiology 38 222-225.

Ribeiro MO, Carvalho SD, Schultz JJ, Chiellini G, Scanlan TS, Bianco AC \& Brent GA 2001 Thyroid hormone-sympathetic interaction and adaptive thermogenesis are thyroid hormone receptor isoform-specific. Journal of Clinical Investigation 108 97-105.

Ross DS 1994 Hyperthyroidism, thyroid hormone therapy, and bone. Thyroid 4 319-326.

Sadow PM, Chassande O, Gauthier K, Samarut J, Xu J, O'Malley BW \& Weiss RE 2003 Specificity of thyroid hormone receptor subtype and steroid receptor coactivator-1 on thyroid hormone action. American Journal of Physiology. Endocrinology and Metabolism 284 E36-E46.

Schwartz HL, Strait KA, Ling NC \& Oppenheimer JH 1992 Quantitation of rat tissue thyroid hormone binding receptor isoforms by immunoprecipitation of nuclear triiodothyronine binding capacity. Journal of Biological Chemistry 267 11794-11799.

Shin DJ, Plateroti M, Samarut J \& Osborne TF 2006 Two uniquely arranged thyroid hormone response elements in the far upstream $5^{\prime}$ flanking region confer direct thyroid hormone regulation to the murine cholesterol $7 \alpha$ hydroxylase gene. Nucleic Acids Research 34 3853-3861.

Torrance CJ, Devente JE, Jones JP \& Dohm GL 1997 Effects of thyroid hormone on GLUT4 glucose transporter gene expression and NIDDM in rats. Endocrinology 138 1204-1214.

Trost SU, Swanson E, Gloss B, Wang-Iverson DB, Zhang H, Volodarsky T, Grover GJ, Baxter JD, Chiellini G, Scanlan TS et al. 2000 The thyroid hormone receptor-beta-selective agonist GC-1 differentially affects plasma lipids and cardiac activity. Endocrinology 141 3057-3064.

Villicev CM, Freitas FR, Aoki MS, Taffarel C, Scanlan TS, Moriscot AS, Ribeiro MO, Bianco AC \& Gouveia CH 2007 Thyroid hormone receptor beta-specific agonist GC-1 increases energy expenditure and prevents fat-mass accumulation in rats. Journal of Endocrinology 193 21-29.

Withers PC 1977 Metabolic, respiratory and haematological adjustments of the little pocket mouse to circadian torpor cycles. Respiration Physiology $\mathbf{3 1}$ 295-307.

Yen PM 2001 Physiological and molecular basis of thyroid hormone action. Physiological Reviews 81 1097-1142.

Yu M, Shao D, Liu J, Zhu J, Zhang Z \& Xu J 2007 Effects of ketamine on levels of cytokines, NF-kappaB and TLRs in rat intestine during CLP-induced sepsis. International Immunopharmacology 7 1076-1082.

Received in final form 15 July 2009

Accepted 26 August 2009

Made available online as an Accepted Preprint 26 August 2009 